\title{
Risk factors and outcome of placenta previa: accrete in a tertiary health care center of Punjab, India
}

\author{
Davinder Pal $^{1}$, Nisha Bhagat $^{1 *}$, Ritu Arora $^{2}$
}

\begin{abstract}
${ }^{1}$ Department of Obstetrics and Gynecology, ${ }^{2}$ Department of Pathology, Government Medical College, Amritsar, Punjab, India
\end{abstract}

Received: 09 December 2018

Accepted: 07 January 2019

\section{*Correspondence:}

Dr. Nisha Bhagat,

E-mail: nishabhagat07@yahoo.com

Copyright: () the author(s), publisher and licensee Medip Academy. This is an open-access article distributed under the terms of the Creative Commons Attribution Non-Commercial License, which permits unrestricted non-commercial use, distribution, and reproduction in any medium, provided the original work is properly cited.

\begin{abstract}
Background: The aim of this study was to identify and evaluate risk factors associated with placenta accrete (PA) and its clinical outcome.

Methods: A descriptive, case control study was conducted in department of obstetrics and gynecology, GMC Amritsar in which authors retrospectively reviewed data of 180 patients of placenta previa (PP) over 5 years, categorized as PA (cases; $n=23$ ) or no PA (control; $n=157$ ). Furthermore, these groups were compared as to maternal demographics, intrapartum and postpartum complications and neonatal outcomes. Stepwise logistic regression analysis was done to evaluate the extent to which exposure variable contributed to the incidence of PA including advanced maternal age (AMA), parity, location of placenta and previous caesarian section (CS). Primary aim was to identify and quantify the various risk factors of PA and secondary aim measured incidences of PP, PA and fetomaternal outcome.

Results: The cumulative incidence of PA over 5 years was 2.98 per 1000 deliveries. Accrete rate increased with number of CSs at $4.76 \%$ in patients with no previous CS versus $45.94 \%$ in $\geq 1$ CS ( $<<0.003$ ). Anterior PP (AOR 10.128 CI $2.406-42.632$; p <0.001) and number of previous CSs (AOR 36.405, 95\% CI 2.743 -483.24, p =0.006) were significant risk factors for PA. AMA (OR >30 years: $4.32695 \%$ CI $0.724-25.856$; $\mathrm{p}=0.108$ ), parity (AOR 1 vs 0: 2.526 95\% CI 0.242-26.41; $\mathrm{p}=0.439$ ), prior uterine curettage (AOR $\geq 1$ vs $0: 11.143$ 95\% CI 0.522-9.726; $\mathrm{p}=0.278$ ) although had association with PA but was not statistical significant. Caesarian hysterectomy was done in $95.65 \%$ patients of PA while only 1 patient of PP required hysterectomy $(\mathrm{p}<0.001)$. Neonatal outcome was similar in both groups.

Conclusions: Prior caesarian and anterior PP emerged out as significant predictors of PA. Other risk factors like AMA, multiparous, history of prior uterine curettage, central PP have incremental risk of having PA and such patients should be managed diligently to lower feto-maternal morbidities and mortalities.
\end{abstract}

Keywords: Caesarian hysterectomy, Placenta accrete (PA), Placenta previa (PP), Risk factors

\section{INTRODUCTION}

Placenta accrete (PA) is defined as any abnormal adherence of the placenta to the uterine wall ("accretism") Diagnosis is based on clinical and histological findings using (i) histopathologic confirmation on a hysterectomy specimen by absence of the intervening layer of decidua, Nitabuch's layer, between placenta and myometrium (ii) incomplete manual removal of the placenta despite active management of the third stage of labor or (iii) heavy continued bleeding from the implantation site of a wellcontracted uterus after difficult removal of the placenta during caesarean section (CS). ${ }^{1-5}$ Given the rising 
incidence of cesarean sections over the last several decades, cases of placenta accrete have been on the rise as well and are now estimated at 1 in every 530 pregnancies. ${ }^{6,7}$ It is associated with $7 \%$ mortality rate, as well as intraoperative and postoperative morbidity caused by massive blood transfusions, infection, and adjacent organ damage. ${ }^{8}$ Although prior uterine surgery, advanced maternal age (AMA), grand multiparity, myomectomy and curettage in addition to caesarean section all have been associated with abnormal placentation but more ominously placenta previa (PP) has been associated with a high rate of PA. ${ }^{9}$ Sonographic determination of placental position, where its location beneath the uterine incision is very important to predict maternal outcome in $\mathrm{PP}$ and such cases close attention should be paid for massive haemorrhage.

Women with both previous CS and PP have high incidence of PA. So, it needs high index of suspicion of abnormal placental invasion in such women and preparation for delivery should be made accordingly. ${ }^{10}$ Antenatal diagnosis is critical as well as pre-operative identification with scheduled cases. Currently the management options or morbidly adherent placenta (MAP) include conservative and extirpative approaches. ${ }^{11}$ The conservative strategy entails leaving the placenta in situ which may be followed by medical management with methotrexate, uterine artery embolization, internal iliac artery ligation/embolization, dilatation and curettage or Hysteroscopic loop resection. ${ }^{12,13}$ However, risk of sepsis and delayed haemorrhage is also incurred. The extirpative approach consists of immediate cesarean hysterectomy, avoiding placental removal during operation which is associated with significant reduced morbidity and therefore it is considered as gold standard. ${ }^{14,15}$ This study was carried out to find the epidemiologic risk factors, which can govern the occurrence of PA in cases of PP. In addition, the associated increased morbidity is quantified.

\section{METHODS}

It was a descriptive, observational, case control study conducted in Department of Obstetrics and Gynecology, GMC, Amritsar. Ethical clearance was obtained from the hospital before the commencement of the study. Institutional records of 5 years from January 2013 to December 2017 were data mined. Total number of deliveries both vaginal births and $\mathrm{CS}$, in this period were retrieved. Out of these, there were 180 patients of PP which were further divided into two groups; with PA (cases; $\mathrm{n}=23$ ) and without PA (control; $\mathrm{n}=157$ ). Data analyzed included baseline demographic variables like maternal age, parity, gestational age, number of previous CS or abortions and placental localization (anterior, central or posterior). Diagnosis of PP and PA was done either preoperative, intraoperative or postpartum. Preoperative detection was done on the basis of ultrasound examination (USG), intraoperative by naked eye examination and inability to remove placenta and postpartum by morbidly adherent placenta after vaginal delivery. PP was conventionally divided into three categories according to its localization i.e. anterior, central or posterior. PA included placenta accrete, placenta increta (histological diagnosis) and placenta percreta (USG based or naked eye). Cases of PA diagnosed preoperatively on USG were operated electively in a planned way. Fetus was extracted by classical CS with placenta left in situ followed by subtotal hysterectomy. Intra-operatively diagnosed cases also underwent hysterectomy in addition to ligation of hypogastric artery in few cases. One case of partial PA was managed by keeping placenta in situ and followed by injections methotrexate and serial USG examination to detect degeneration of placental tissue. Subtotal hysterectomy was done in PA cases diagnosed after vaginal delivery. Maternal outcome was measured in terms of number of units of blood products required, intra and postoperative complications till 42 days of the follow up period, ICU admissions, prolonged hospital stay, maternal morbidity and mortality. Neonatal outcome in terms of Apgar score, birth weight, gender and mortality were also analyzed. Primary aim was to identify and to statistically quantify the various risk factors associated with PA and secondary aim measured incidence of PP, PA and fetomaternal outcome.

\section{Statistical analysis}

The database was compiled in a Microsoft Excel document and later exported to a SAS dataset for analytical deep dive exercise using Statistical Analytical System (SAS) version 9.3. A step towards verifying the sanity of data involved evaluating mean standard deviation for continuous variables and frequency of discreet variables. Cases and control groups were compared using Student's t-test. To determine association of risk factors (e.g. AMA, parity, previous surgeries, location of placenta etc.) with PA, Adjusted Odds Ratios (AOR) with $95 \%$ Confidence interval (CI) were calculated using multivariate logistic analysis with adjustments made for the covariate. $\mathrm{P}$ value of $5 \%$ has been considered as the threshold to categorize a risk factor as statistically significant.

\section{RESULTS}

A total of 7713 patients delivered in five years with 3983 vaginal births and 3730 Lower Segment Cesarean Section (LSCS). There were 180 cases of PP and out of which 23 were having PA (cases) giving a cumulative incidence of 23.25 and 3.11 per 1000 births respectively over 5 years. Yearly incidence of PP and PA is shown in Table 1 with incidence increasing from 1.27 per 1000 births in year 2013 to 5.15 per 1000 births in 2017. The sociodemographic characteristics of both cases and control and associated risk factors is shown in Table 2. Mean age of PA was $28.83 \pm 3.89$ years while that of PP was $26.26 \pm 3.97$ years. Seventeen patients $(73.91 \%)$ of PA had history of prior CS and $5(21.73 \%)$ patients had prior uterine curettage. 
Table1: Incidence of placenta previa and placenta accrete.

\begin{tabular}{|c|c|c|c|c|c|c|c|c|}
\hline Year & $\begin{array}{l}\text { Total } \\
\text { deliveries } \\
\text { (n) }\end{array}$ & $\begin{array}{l}\text { NVD* } \\
\text { (n) }\end{array}$ & $\begin{array}{l}\operatorname{LSCS} \dagger \\
\text { (n) }\end{array}$ & $\begin{array}{l}P P \neq \\
(n=180)\end{array}$ & $\begin{array}{l}\text { Incidence } \\
\text { PP (per } 1000 \\
\text { births) }\end{array}$ & $\begin{array}{l}\text { PA§ } \\
(\mathrm{n}=23)\end{array}$ & $\begin{array}{l}\text { Incidence } \\
\text { PA (per } \\
1000 \text { births) }\end{array}$ & $\begin{array}{l}\text { Incidence of } \\
\text { PA in PP } \\
(\%)\end{array}$ \\
\hline 2013 & 1573 & 729 & 844 & 46 & 29.24 & 2 & 1.27 & 4.3 \\
\hline 2014 & 1851 & 967 & 884 & 46 & 24.85 & 5 & 2.70 & 10.86 \\
\hline 2015 & 1380 & 718 & 662 & 24 & 17.39 & 3 & 2.17 & 12.5 \\
\hline 2016 & 1552 & 850 & 702 & 41 & 26.41 & 6 & 3.86 & 14.63 \\
\hline 2017 & 1357 & 719 & 638 & 23 & 16.94 & 7 & 5.15 & 30.3 \\
\hline Total & 7713 & 3983 & 3730 & 180 & 23.33 & 23 & 2.98 & 12.77 \\
\hline
\end{tabular}

*NVD: Normal Vaginal Delivery; †LSCS: Lower Segment Cesarean Section; $₫$ PP: Placenta Praevia; §PA: Placenta Accrete

Table 2: Patient characteristics and risk factor assessment.

\begin{tabular}{|c|c|c|c|c|c|c|c|}
\hline & & $\begin{array}{l}\text { Cases } \\
(\mathbf{P A}) * \\
\mathbf{n}=\mathbf{2 3}(\%)\end{array}$ & $\begin{array}{l}\text { Control } \\
(\mathrm{PP}) \div \\
\mathrm{n}=\mathbf{1 5 7}(\%)\end{array}$ & $\begin{array}{l}\text { UOR\$ } \\
(95 \% \mathrm{CI}) * *\end{array}$ & P value & $\begin{array}{l}\text { AOR } \| \\
(95 \% \mathrm{CI})\end{array}$ & $\begin{array}{l}P \\
\text { value }\end{array}$ \\
\hline \multirow{4}{*}{$\begin{array}{l}\text { Age (in } \\
\text { years) }\end{array}$} & $<25$ & $3(13.04)$ & $55(35.03)$ & 1 & & 1 & \\
\hline & $25-30$ & $10(43.47)$ & $72(45.85)$ & $2.55(0.67-9.70)$ & 0.171 & $1.66(0.32-8.75)$ & 0.549 \\
\hline & $>30$ & $10(43.47)$ & $30(19.10)$ & $6.11(1.56-23.92)$ & 0.009 & $4.326(0.72-25.86)$ & 0.108 \\
\hline & Mean $\pm \mathrm{SD}^{\dagger \dagger}$ & $28.83 \pm 3.89$ & $26.26 \pm 3.97$ & & & & \\
\hline \multirow{5}{*}{ Parity } & 0 & $1(4.3)$ & $50(31.84)$ & 1 & & 1 & \\
\hline & 1 & $11(47.82)$ & $59(37.57)$ & $9.32(1.16-74.73)$ & 0.036 & $2.53(0.24-26.41)$ & 0.439 \\
\hline & 2 & $5(21.73)$ & $31(19.745)$ & $8.07(0.9-72.30)$ & 0.062 & $0.427(0.016-11.6)$ & 0.613 \\
\hline & $>2$ & $6(26.08)$ & $17(10.82)$ & $17.65(1.98-157.26)$ & 0.010 & $2.818(0.19-42.03)$ & 0.453 \\
\hline & Mean \pm SD & $1.78 \pm 1.09$ & $1.16 \pm 1.14$ & & & & \\
\hline \multirow{5}{*}{$\begin{array}{l}\text { Previous } \\
\mathrm{CS}^{\dagger}\end{array}$} & 0 & $6(26.08)$ & $120(76.43)$ & 1 & & 1 & \\
\hline & 1 & $7(30.43)$ & $25(15.92)$ & $5.60(1.73-18.09)$ & 0.004 & $5.206(1.15-23.63)$ & 0.033 \\
\hline & 2 & $6(26.08)$ & $8(5.09)$ & $15.00(3.93-57.22)$ & $<0.0001$ & $36.405(2.74-83.24)$ & 0.006 \\
\hline & 3 & $4(17.39)$ & $4(2.5)$ & $20.00(3.99-100.08)$ & 0.0003 & $5.395(0.596-48.86)$ & 0.134 \\
\hline & Mean \pm SD & $1.35 \pm 1.07$ & $0.34 \pm 0.69$ & & & & \\
\hline \multirow{3}{*}{$\begin{array}{l}\text { Uterine } \\
\text { curettage }\end{array}$} & 0 & $18(78.26)$ & $138(87.89)$ & 1 & & 1 & \\
\hline & $\geq 1$ & $5(21.73)$ & $19(12.10)$ & $2.02(0.671-6.066)$ & 0.211 & $11.143(0.522-9.726)$ & 0.2783 \\
\hline & Mean \pm SD & $0.22 \pm 0.42$ & $0.12 \pm 0.33$ & & & & \\
\hline \multirow{3}{*}{$\begin{array}{l}\text { Placenta } \\
\text { position }\end{array}$} & Posterior & $3(13.04)$ & $100(63.69)$ & 1 & & 1 & \\
\hline & Anterior & $18(78.26)$ & $45(28.66)$ & $13.33(3.73-47.56)$ & $<0.0001$ & $10.128(2.41-42.632)$ & 0.002 \\
\hline & Central & $2(8.6)$ & $12(7.6)$ & $5.55(0.842-36.49)$ & 0.075 & $5.139(0.54-49.11)$ & 0.155 \\
\hline \multirow{4}{*}{$\begin{array}{l}\text { Gestation } \\
\text { al age (in } \\
\text { weeks) }\end{array}$} & $<32$ & $5(21.73)$ & $13(8.2)$ & 1 & & & \\
\hline & $32-36$ & $4(17.39)$ & $51(32.48)$ & $0.20(0.048-0.868)$ & 0.032 & $0.999(0.041-1.816)$ & 0.05 \\
\hline & $>36$ & $14(60.86)$ & $93(59.23)$ & $0.39(0.121-1.267)$ & 0.118 & $1.899(0.133-3.604)$ & 0.2242 \\
\hline & Mean \pm SD & $34.04 \pm 5.78$ & $35.67 \pm 2.66$ & & & & \\
\hline \multirow{2}{*}{ F. gender } & Male & $15(65.21)$ & $84(53.50)$ & 1 & & & \\
\hline & Female & $8(34.78)$ & $73(46.49)$ & $0.61(0.246-1.53)$ & 0.295 & & \\
\hline
\end{tabular}

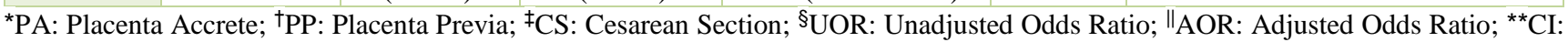
Confidence Interval; ${ }^{\dagger \dagger}$ SD: Standard Deviation

Diagnosis of PA was made during antenatal period in 19 cases, intraoperatively in 3 patients and 1 case was diagnosed postpartum while unsuccessful attempt of removing placenta.

Incidence of PA among PP was higher in women with AMA as compared to $<30$ years (25\% vs $10.23 \%$; $\mathrm{p}=0.009$ ). In patients less than 25 years of age, incidence was $5.17 \%$, between $25-30$ years it was $12.19 \%$ and in patients more than 30 years, incidence rose to $25 \%$ which was statistically significant $(\mathrm{p}=0.009)$.

Similar observations were seen with increase in parity at the rate of $2 \%, 15.71 \%, 13.8 \%$ and $26.08 \%$ in patients with $0,1,2$ and more than 2 parity respectively $(\mathrm{p}=0.010)$. Accrete rate was $4.76 \%$ in patients with no previous CS versus $45.94 \%$ in $\geq 1 \mathrm{CS}(\mathrm{p}<0.003)$. It was $21.8 \%, 42.85 \%$ and $50 \%$ in previous 1,2 and $\geq 3$ CS respectively. 
Patients with anterior PP had $28.57 \%$ incidence of PA as compared to $2.91 \%$ in posterior placenta ( $p<0.0001$ ). Although the incidence of PA was higher in prior uterine curretage $(20.83 \%$ vs $11.53 \% ; \mathrm{p}=0.211)$ and with central PP (14.28\% versus $2.91 \% ; \mathrm{p}=0.075)$ the difference did not reach statistically significance.

Variables like AMA, parity, number of previous CS, number of prior uterine curettage, placental localization and gender of the baby were selected for stepwise multiple logistic regression out of which uterine scar and anterior PP emerged out as statistically significant risk factors for development of PA. The risk of having PA was 36 times more with 2 or more previous surgeries than unscarred uterus (AOR 36.405 95\%CI2.743-483.241; $\mathrm{p}=0.006)$.

In patients with anterior PP the risk was 10 times more than with posterior PP (AOR10.128; 95\%CI2.40642.632; $\mathrm{p}=0.002)$. Only one patient of PP underwent caesarian hysterectomy due to intractable obstetrical haemorrhage not controlled by stepwise devascularisation.
Table 3: Maternal outcome and complications.

\begin{tabular}{|c|c|c|c|}
\hline $\begin{array}{l}\text { Complication/ } \\
\text { outcome }\end{array}$ & $\begin{array}{l}\text { Cases } \\
\text { n }(\%)\end{array}$ & $\begin{array}{l}\text { Control } \\
\text { n }(\%)\end{array}$ & P value \\
\hline Shock & $2(8.6)$ & $8(5.09)$ & 0.487 \\
\hline \multicolumn{4}{|c|}{ Number of blood units } \\
\hline$<3$ units & $2(8.6)$ & $118(75.15)$ & \\
\hline$>3$ units & $21(91.30)$ & $39(24.84)$ & $<0.0001$ \\
\hline $\begin{array}{l}\text { Mean } \pm \text { SD } \\
\text { (number of } \\
\text { blood units) }\end{array}$ & $4.4 \pm 1.9$ & $1.7 \pm 1.5$ & \\
\hline Bladder Injury & $3(13.04)$ & 0 & \\
\hline $\begin{array}{l}\text { Partial } \\
\text { cystectomy }\end{array}$ & $2(8.6)$ & 0 & \\
\hline Hysterectomy & $22(95.65)$ & $1(.063)$ & $<0.0001$ \\
\hline Sepsis & $1(4.34)$ & 0 & \\
\hline ICU admission & $5(21.73)$ & $12(7.6)$ & 0.039 \\
\hline $\begin{array}{l}\text { Prolonged } \\
\text { hospital stays } \\
\text { (>10 days) }\end{array}$ & $7(30.43)$ & $12(7.6)$ & 0.03 \\
\hline $\begin{array}{l}\text { Maternal } \\
\text { mortality }\end{array}$ & $1(4.34)$ & 0 & \\
\hline
\end{tabular}

Table 4: Neonatal outcome.

\begin{tabular}{|c|c|c|c|c|}
\hline Variable & Outcome & $\begin{array}{l}\text { Cases } \\
\text { n }(\%)\end{array}$ & $\begin{array}{l}\text { Control } \\
\mathrm{n}(\%)\end{array}$ & P value \\
\hline \multirow{2}{*}{ Dead/Alive } & Alive & $19(82.60)$ & $151(96.17)$ & \\
\hline & Dead & $4(17.39)$ & $6(3.8)$ & 0.016 \\
\hline \multirow{2}{*}{ Gestation } & $<37$ weeks & $14(60.86)$ & $94(59.87)$ & \\
\hline & $\geq 37$ weeks & $9(39.13)$ & $63(40.12)$ & 0.928 \\
\hline Mean gestation age \pm SD (in weeks) & & $34.04 \pm 5.78$ & $35.67 \pm 2.66$ & \\
\hline \multirow{3}{*}{ Birth weight } & $<2.5 \mathrm{~kg}$ & $7(30.43)$ & $46(29.29)$ & \\
\hline & $2.5-3 \mathrm{~kg}$ & $12(52.17)$ & $63(40.12)$ & 0.662 \\
\hline & $\geq 3 \mathrm{~kg}$ & $4(17.39)$ & $48(30.57)$ & 0.362 \\
\hline Mean birth weight \pm SD & & $2.4 \pm 0.9$ & $2.7 \pm 0.6$ & \\
\hline \multirow{2}{*}{ Fetal sex } & Male & $15(65.21)$ & $84(53.50)$ & \\
\hline & Female & $8(34.78)$ & $73(46.49)$ & 0.295 \\
\hline \multirow{2}{*}{ APGAR score (1 minute) } & $<6$ & $8(34.78)$ & $46(29.29)$ & \\
\hline & $\geq 6$ & $15(65.21)$ & $111(70.70)$ & 0.593 \\
\hline Mean Apgar \pm SD & & $5.3 \pm 3.2$ & $6.4 \pm 1.6$ & \\
\hline \multirow{2}{*}{ Apgar (5 minute) } & $<8$ & $6(26.08)$ & 27 (17.19) & \\
\hline & $\geq 8$ & $17(73.92)$ & $130(82.80)$ & 0.308 \\
\hline Mean Apgar \pm SD & & $6.9 \pm 3.8$ & $8.6 \pm 1.2$ & \\
\hline NICU admission & Yes & $4(17.39)$ & $28(17.83)$ & 0.959 \\
\hline
\end{tabular}

Significantly more amount of blood units was transfused in PA than PP $(4.4 \pm 1.9 \mathrm{vs} 1.7 \pm 1.5 ; \mathrm{p}<0.001)$ so were the days of prolonged hospital stay (30.43\%vs7.6\%; $\mathrm{p}=0.039$ ). $91.30 \%$ of patients with PA required more than 3 units of blood transfusion whereas only one fourth of PP $(24.8 \%)$ required more than 3 units. There was one maternal mortality in PA group as it was an undiagnosed case of placenta percreta, detected on operation table. She had massive intraoperative bleeding, was transfused with 20 units of blood products but despite best efforts she developed multiorgan failure and disseminated Intravascular Coagulation (DIC) and succumbed to complications. PP group had no maternal mortality. Table 4 Neonatal outcome was comparable in both 
groups in regard to prematurity, mean APGAR score, mean birth weight, NICU admissions but significantly a greater number of neonates survived in PP group (96.17\% vs $82.60 \%$ live birth; $\mathrm{p}=0.016$ ). This difference may be attributed to iatrogenic prematurity in PA cases where early and elective delivery is required.

\section{DISCUSSION}

PA is one of the major risk factors for massive obstetrical hemorrhage leading to maternal morbidity and fetal compromise especially in unplanned and emergency surgeries. A recent study from Hong Kong found that the prevalence of PAS disorders increased from 0.17 per 1000 births in the period $1999-2003$ to 0.79 per 1000 births in the period 2009-2013. ${ }^{16}$ Aggarwal et al reported an increase in incidence of PA from $0.01 \%$ in 2002 to $0.05 \%$ in $2006 .{ }^{17}$ Chaudhari et al, reported an incidence of $1.32 / 1000$ deliveries while in present study the cumulative incidence in 5 years was 2.98/1000 deliveries with an increase in rate from 1.27 per 1000 deliveries in 2013 to 5.15 per 1000 deliveries in $2017 .{ }^{18}$ Usta et al, observed an incidence rate of accrete in previa cases being $6.3 \%$ whereas in present study this rate was $12.77 \%$ which may be attributed to rising number of CS over few years. ${ }^{19}$ Literature has identified various risk factors associated with PA as AMA, grand-multiparity, previous CS, history of prior uterine curettage, Placenta $\mathrm{P}$, smoking, hypertension.

\section{Age}

The incidence of PA in study conducted by Usta et al, was significantly higher in patients with AMA compared with those $<35$ years $(13.6 \%$ vs $4.1 \%, \mathrm{P}=0.005)$ but it didn't emerge out as independent risk factor. Accrete rate was $3.3 \%$ in those $<25$ years, $3.4 \%$ in those 25 to 29 years, $5.5 \%$ in those 30 to 34 years, and $13.6 \%$ in those with AMA. ${ }^{19}$ AMA (>35years) has been identified as independent and significant risk factor for development of PA in studies conducted by Wu et al, (OR 1.13, 95\% CI 1.08-1.19; p < 0.0001), Hung et al, (OR 3.2, 95\% CI 1.1- 9.4; $\mathrm{p}<0.01$ ), Kennare et al, (OR 18.79, 95\% CI 2.28864.6) and Fitzpatrick et al, (OR 3.48, 95\% CI 1.52-7.96, $\mathrm{p}<0.0032){ }^{3,4,20,21}$ In present study, incidence of accrete was $5.17 \%$ in those $<25$ years, $12.19 \%$ between $25-30$ years and in patients more than 30 years, incidence rose to $25 \%$ which was statistically significant at $p$ value of 0.009 . Although women more than 30 years of age were at 4 times more risk for accretism than $<25$ years (AOR $4.32695 \%$ CI $0.724-25.856$ ) but it did not emerge out as significant independent risk factor $(\mathrm{p}=0.108)$. The reason for this may be less age of marriage and subsequent conceptions in India as compared to western world.

\section{Parity}

In present study, the risk of PA was 3 times more in women with $\geq 2$ parity than in nulliparous women with an incidence of $26.08 \%$ among PP patients but it was not an independent risk factor (AOR 2.818 95\% CI 0.18942.032; $\mathrm{p}=0.453$ ). These findings were in contrast to study done by Hung et al, which established grandmultiparity i.e., $>5$ as a significant risk factor for accrete (OR1: $0.30 \quad 95 \%$ CI $0.10-1.40) ;(\mathrm{OR}>5: 3.90 \quad 95 \%$ CI 0.70- 21.8; $\mathrm{p}<0.01)$ while Usta et al, and Fitzpatrick et al, did not find it as a significant predictor. ${ }^{4,19,21}$ Grandmultiparity is rarely seen in modern era due to acceptance of various family planning programs.

\section{Previous caesarian section}

Prior CS is one of the major risk factor for PA as found by Gielchinsky et al, (OR $3.30(0.90-12.5)$; Wu et al (OR 1CS: 2.16 95\% CI 0.96-4.86; $\mathrm{p}=0.064 ;$ OR $\geq 2$ CS: 8.62 95\% CI 3.53-21.07; $\mathrm{p}<0.001$ ) and Hung et al, (OR 1: 2.3 $(0.50-9.50) \mathrm{p}<0.06$ and Usta et al, $(>1$ CS OR 30.5, 95\% CI 8.2-113.6; $\mathrm{P}<.001) .{ }^{2-4,19}$ In present study too, more than 2 CSs had 36 times increased risk of PA than unscarred uterus (AOR 36.405 95\% CI 2.743-483.241; $\mathrm{p}=0.06$ ). Our findings were also consistent with study done by Zaki et al, where the incidence of accrete showed a gradual increase from $4.1 \%$ in patients with no history of CS to $60 \%$ in patients with a history of three or more previous CS. ${ }^{22}$

Prior uterine curettage: The risk of having PA was 11 times more in patients with one or more prior curettage than no curettage (AOR $\geq 1 \mathrm{vs} 0: 11.143$ 95\% CI 0.522 9.726; $\mathrm{p}=0.278$ ) in present study though the difference was not statistically significant. Similar outcomes were also observed by Usta et al, in patients with recurrent abortions $(13.0 \%$ vs $5.9 \% ; \mathrm{p}=0.171) .{ }^{19}$

\section{Placental localization}

Anterior or central placental location was found to be a significant risk factor in the presence of a previous scar (28.6\% vs $7.6 \%$; $\mathrm{p}<0.001)$ but not in its absence as seen by Usta et al $(2.4 \%$ vs $6.0 \% ; \mathrm{p}=0.239) .{ }^{19}$ Gielchinsky et al, (OR: 6.1, 95 \% CI 1.4-25.3) reported anterior low lying placenta as a risk factor. ${ }^{2}$ Similar observations were also made by Farquhar et al (AOR:36.3 (14.0 to93.7). ${ }^{23}$ Incidences of placental accrete (OR 2.94; 95\% CI: 1.63 5.29) and hysterectomy (OR 4.24; 95\% CI: 1.77-10.17) were much more common in the anterior group as reported by Jang et al.24 Similarly, Bowman et al and Zhang et al also found PP a potential risk factor for accrete with AOR of 4.9 (95\% CI, 1.7-14.3)and 15.952 (95\% CI: 4.701-54.127) respectively. ${ }^{25,26}$ Present study too identified anterior PP (AOR 10.128, 95\% CI: 2.406 42.632; $\mathrm{p}<0.001)$ as a significant risk factor.In addition to above, some studies have also identified other factors like hypertensive disorders (OR13.9, 95\% CI 2.1-91.2; $\mathrm{p}=0.006)$, smoking (OR 3.4, 95\%CI 1.1-10.2; $\mathrm{p}=0.031)$, second-trimester alfa feto protein (AFP) and $\beta$-hCG> 2.5 median of mean, fetal male gender and In Vitro fertilisation (IVF) pregnancy as an important risk factors for PA but among them only second trimester AFP and $\beta$ hCG were the significant predictor. ${ }^{27}$ 
Maternal mortality in present study was $4.34 \%$ which was comparable to Chaudhari et al, and far lesser than Aggarwal et al at 3\% and 30\% respectively. ${ }^{17,18}$

The main neonatal complication was prematurity with mean gestation of $34.04 \pm 5.78$ weeks and mean birth weight of $2.4 \pm 0.9 \mathrm{~kg}$ which was similar to neonatal outcome observed by aggarwal et al, with average gestational age of 35.2 weeks and an average birth weight of $2.25 \mathrm{~kg} .1760 .86 \%$ babies in present study were preterm and $17.39 \%$ required NICU admission. These findings were comparable with study conducted by Chaudhary et al, who found that $57 \%$ of the babies were preterm and $27 \%$ required NICU admission. ${ }^{18}$

\section{CONCLUSION}

In recent years increase in CS rate has led to drastic rise in the rate of PA. Identifying the associated risk factors can help in planning and managing PA timely and effectively thus preventing major feto-maternal morbidities and mortalities. Patients with anterior PP, history of prior CS or uterine curettage, AMA and multiparous women should be considered important predictors of PA and should be treated diligently.

Funding: No funding sources

Conflict of interest: None declared

Ethical approval: The study was approved by the Institutional Ethics Committee

\section{REFERENCES}

1. Oyelese Y, Smulian JC. Placenta previa, placenta accrete, and vasa previa. Obstet Gynecol. 2006;107:927-41.

2. Gielchinsky Y, Rojansky N, Fasouliotis SJ, Ezra Y. Placenta accrete-summary of 10 years: a survey of 310 cases. Placenta. 2002;23:210-4.

3. Wu S, Kocherginsky M, Hibbard JU. Abnormal placentation: twenty-year analysis. Am J Obstet Gynecol. 2005; 192:1458-61.

4. Hung TH, Shau WY, Hsieh CC, Chiu TH, Hsu JJ, Hsieh TT. Risk factors for placenta accrete. Obstet Gynecol. 1999; 93:545.

5. Benirschke KKP, Kaufmann P. Pathology of the human placenta, $4^{\text {th }}$ ed. New York: Springer, 2000.

6. Wax JR, Seiler A, Horowitz S, Ingardia CJ. Interpregnancy interval as a risk factor for placenta accrete. Conn Med. 2000;64:659-1.

7. Gielchinsky Y, Mankuta D, Rojansky N, Laufer N, Gielchinsky I, Ezra Y. Perinatal outcome of pregnancies complicated by placenta accrete. Obstet Gynecol. 2004;104:527-30.

8. O'Brien JM, Barton JR, Donaldson ES. The management of placenta percreta: conservative and operative strategies. Am J Obstet Gynecol. 1996;175:1632-8.

9. Bahar A, Abusham A, Eskandar M,Sobande A, Alsunaidi M. Risk factors and pregnancy outcome in different types of placenta previa. J Obstet Gynaecol Can. 2009;31:126-31.

10. Clark SL, Koonings PP, Phelan JP. Placenta previa/accrete and prior cesarean section. Obstet Gynecol. 1985;66:89-2.

11. Kayem G, Davy C, Goffinet F, Thomas C, Clément D, Cabrol D. Conservative versus extirpative management in cases of placenta accrete. Obstet Gynecol. 2004;104(3):531-6.

12. Bennett MJ, Sen RC. 'Conservative' management of placenta praeviapercreta: report of two cases and discussion of current management options. Aust N Z J Obstet Gynaecol.2003;43:249-51.

13. Mussalli GM, Shah J, Berck DJ, Elimian A, Tejani N, Manning FA. Placenta accrete and methotrexate therapy: three case reports. J Perinatol. 2000;20:3314.

14. Jagielska I, Kazdepka-Ziemińska A, Tyloch M, Żołnieżewicz K, Grabiec M, Szymański W, et al. Clinical study of perinatal hysterectomy between 2000-2011 in the clinic of obstetrics, gynecological diseases and oncological gynecology in Bydgoszcz. Ginekol Pol.2014;85(3).

15. Roethlisberger M, Womastek I, Posch M, Husslein P, Pateisky N, Lehner R. Early postpartum hysterectomy: incidence and risk factors. Acta Obs Gynecol Scand. 2010;89(8):1040-4.

16. Cheng KK, Lee MM. Rising incidence of morbidly adherent placenta and its association with previous caesarean section: A 15-year analysis in a tertiary hospital in Hong Kong. Hong Kong Med J. 2015; 21:511-7.

17. Aggarwal R, Suneja A, Vaid N B, Yadav P, Sharma A, Mishra K. Morbidly adherent placenta: a critical review. J Obstet Gynecol. 2012; 62(1):57-61.

18. Chaudhari HK, Shah PK, D'Souza N. Morbidly adherent placenta: Its management and maternal and perinatal outcome. J Obstet Gynaecol India. 2017;67(1):42-7.

19. Usta IM, Hobeika EM, Musa AA, Gabriel GE, Nassar AH. Placenta previa-accrete: risk factors and complications. Am J Obstet Gynecol. 2005;193:1045-9.

20. Kennare R, Tucker G, Heard A, Chan A. Risks of adverse outcomes in the next birth after a first cesarean delivery. Obstet Gynecol. 2007;109(1):2706.

21. Fitzpatrick KE, Sellers S, Spark P, Kurinczuk JJ, Brocklehurst P, Knight M. Placenta accrete/increta/percreta: incidence, risk factors, management and outcomes. Arch Dis Child Fetal Neonatal Ed. 2012; 97(1):A4-5.

22. Zaki ZM, Bahar AM, Ali ME, Albar HA, Gerais MA. Risk factors and morbidity in patients with placenta previa accrete compared to placenta previa non-accrete. Acta Obstet Gynecol Scand. 1998;77(4):391-4.

23. Farquhar CM, Li Z, Lensen S, McLintock C, Pollock $\mathrm{W}$, Peek MJ, et al. Incidence, risk factors and perinatal outcomes for placenta accreta in Australia 
and New Zealand: a case-control study. BMJ open. 2017;7(10):e017713.

24. Jang DG, We JS, Shin JU, Choi YJ, Ko HS, Park IY et al. Maternal outcomes according to placental position in placental previa. Int $\mathbf{J}$ Med Sci. 2011;8(5):439-44.

25. Bowman ZS, Eller AG, Bardsley TR, Greene T, Varner MW, Silver RM. Risk factors for placenta accrete: a large prospective cohort. Am J Perinatol. 2014;31(9):799-804.

26. Zhang D, Yang S, Hou Y, Su Y, Shi H, GuW. Risk factors, outcome and management survey of placenta accrete in 153 cases: a five-year experience from a hospital of Shanghai, China. Int J Clin Exp Med. 2017;10(8):12509-16.

27. Balayla J, Bondarenko HD. Placenta accrete and the risk of adverse maternal and neonatal outcomes. J Perinat Med. 2013;41(2):141-9.

Cite this article as: Pal D, Bhagat N, Arora R. Risk factors and outcome of placenta previa: accrete in a tertiary health care center of Punjab, India. Int J Reprod Contracept Obstet Gynecol 2019;8:658-64. 